\title{
REDAKSIONEEL
}

\section{HET CHRISTUS TWEE GESIGTE IN GEREFORMEERD}

\section{NEDERLAND?}

IN Centraal Weekblad, 'n kerklike blad onder redaksie van $\mathrm{K}$. Runia, debatteer Horst Kleinschmidt (uitgeweke amptenaar van die CI) en J. P. Feddema die vraag of die ANC nou (na die CI) die stem van ,verdrukte" swart mense verteenwoordig! Skynbaar is dit van ,kerklike" belang om 'n kroonprins vir die CI te nomineer en wie ,kerklike" Nederland polities kan steun. So duidelik het politieke praktyk „kerk"-saak geword.

In Geref. Weekblad (26.5.78) vra R. Gosker onder die opskrif „De Hand in eigen boezem" waarom staan gereformeerde Afrikaners, grotendeels geleer, getoog en gekweek in die Nederlandse gereformeerde erfenis en aan Nederlandse instellings solied agter die beleid van veelvolkige ontwikkeling - terwyl Nederlanders tans die beleid as die ergste rassisme verdoem? Sou dieselfde Nederlanders anders in SA geoordeel het, indien hulle in die konkrete situasie verkeer het en verantwoordelik was? Waarom word Nederlanders wat na SA gaan dan slegs in een rigting beïnvloed? Wat doen Nederland nader aan haar huis om armoede in Suid-Italië, Sicilië, Portugal en elders op te los? Hoe vergelyk Nederland se halwe persent bydrae uit nasionale inkomste ten behoewe van die Derde Wêreld met die hoë persentasie wat blanke Suid-Afrika aan ontwikkeling bestee en dit terwyl Nederlanders se inkomste per hoof net so groot of groter as die van Suid-Afrikaners is? Waarom eis Nederlanders onvoorwaardelik politieke magsdeling in SA, terwyl hulle self nie eers bereid is om selfs maar net hulle ekonomiese welvaart (sonder politieke implikasies) gelykop met die Derde Wêreld te deel nie? Waarom laat hulle die ontsaglike taak feitlik net aan „blanke" SA oor, terwyl hulle net fout vind?

Die vrae word natuurlik nie deur die GW beantwoord nie. Die antwoord sou moes lui: Nederland se eie belang en politieke gerigtheid veroorsaak die anomalie. Enkele bladsye verder verduidelik prof. D. C. Mulder, kollega van Verkuyl, waarom die VU nie na die Second International Conference of Institutions for Christian Higher Education in Augustus te Grand Rapids gegaan het nie. 'n Meer selftevrede en selfgeregverdigde stem kan 'n mens jou nie voorstel nie.

Vanuit sy eie hoek waarin alles vir hom so mooi, regverdig en goed is (omdat dit op neo-marxisitese toer van die program van die WRK van Genève is), skryf Mulder oor SA waarin alles so verskriklik onregverdig, onderdrukkend en ongeneesbaar is, omdat die mag eensydig in hande van die "blankes" en vreeslike Vorster-regime is.

Volgens M. het die VU voor 'n keuse te staan gekom. Hulle moes besluit om met "een aantal instituten .... die nog rechtser staan dan 
vele GOS (Ekumeniese Sinode B.S.) leden" en wat van "fundametalistisch en conservatief karakter" is, te assosieer - of die VU moes sy oë buite daardie konferensie op die "oecumenische toekomst" rig. Dit is duidelik dat M. hier die geselskap van die WRK (en daarmee die utopia van 'n sosialistiese wêreldgemeenskap B.S.) kies.

Eerlik en duidelik stel M. dat daar vir die linkse VU eintlik nie 'n keuse was nie. Ek glo dit is die ware rede. Hy gee dan nog 'n paar "goeie redes".

Mulder sê dat die PU vir CHO se deelname aan die Konferensie die VU uitgesluit het. Die PU is die "muishond" omdat, volgens M, (1) die PU nie wou mak soos Mulder en sy ander VU metgeselle hulle in 1976 vier dae lank vertel het nie; (2) dialoog met blanke Afrikaners niks beloof nie en dus moet gesprek met „blankes” afgeskryf word. (M. was ook die persoon wat aan die Sinode GKN in 1975 sou sê wat ds. Ernst Buti eintlik wou sê, en daarmee Buti se toespraak tot die teenoorgestelde verdraai het - 'n set wat kennelik bedoel het om 'n wig in die NGK-familie te drywe sodat die GKN d.m.v. die PCR met die swart Kerke teen die blanke NG Kerke kon aangaan); (3) die PU vir $\mathbf{C H O}$ het nie protesteer toe 'n eredoktor van die VU, nl. Beyers Naude, "de mond gesnoerd" is nie.

'n Blatanter voorbeeld van tradisionale Europese paternalisme teenoor Suid-Afrika kan nie gevind word nie. Dit is duidelik: die norm vir assosiasie, selfs vir blote gesprek, het die vraag geword of die SA instansie na prof. M. sal luister en maak soos hy vir hom sê! Hoe effektief is die hele VU rondom 'n eredoktersgraad aan 'n persoon gekoppel, om te gebruik in die verpolitiseerde linkse kerkstrategie!

Die tragiek is egter dat hierdie gees in 'n kerklike blad, deur 'n gereformeerde missioloog (d.w.s. onder Christelike dekmantel) ten opsigte van 'n konferensie van die so min Gereformeerde inrigtings in die wêreld van vandag gedoen word!

Openbaar M. se gesindheid die beeld van Christus?

In die skrywe van Gosker kan ek minstens die Christelike gewete hoor wanneer hy worstel met die problematiek van "broeders" (al is hulle blank) in veraf SA. By M. kan ek geen gewete gewaar wat deur Skrifnorme beheers word nie. Sy breuk en afskryf van "blanken" (sonder om hulle eers genuanseerd uit 'n geloofsoogpunt te probeer identifiseer) is genormeer deur sy omgekeerde "rassisme” en kontemporêre politiek. Dit is duidelik dat die Kairosgeledere die skema van hierdie eeu (Rom. 12:2), naamlik die neo-marxistiese rewolusie, sjibboleth vir hulle „koinonia” gemaak het.

In die beoefening van die Gereformeerde teologie sal ons met hierdie polarisasie moet rekening hou. Hierdie mense het gekies. Ons sal duidelik moet onderskei wie nog die identiteit van Gereformeerd, Skrifgelowige en Konserwatief (in reformatoriese sin) wil dra - en wie die blote naam van "gereformeerd" gebruik om nog 'n struktuur, nog ' $n$ bestaande organisasie, in te span by die "program" of agenda van die linkse wêreldrewolusie. Selfs kerklik sal ons minder 'n gespreksbasis moet ,,aanneem”. Ons sal ons weer duidelik moet identifiseer deur Konfessie - soos in alle groot historiese krisisse - (mede bewerk deur die tydsgees en politiek van daardie dae) $1600-1618$, $1834,1859,1886$ - nodig was. 


\section{Second International Conference of Institusions for Christian Higher Education-'n finale kruispad?}

Die agtergrond van die Konferensie is bekend. Die gedagte (oorspronklik van prof. J. Chris Coetzee?) was dat Christelike (Gereformeerde?) Hoër Onderwysinrigtings ook 'n vorm van ekumeniese „,sinode" moes hou om hulle moeilike taak in die gekompliseerde wêreld van vandag te dien. Die PU vir CHO het deur die sending van prof. J. C. Coetzee (jr) met groot koste en moeite die eerste Konferensie in Potchefstroom bewerkstellig. Daarop het die tweede gevolg. Die VU het uit die staanspoor hulle van die tweede gedistansieer, omdat die PU vir CHO daaraan deelneem. Alles wat die Regering van SA doen waarvan die VU nie hou nie, was die PU vir CHO se verantwoordelikheid - die ou bekende boikot-motief.

'n Gesprek met kollega L. J. Botha wat daar teenwoordig was, het ernstige vrae opgeroep. Die presensie-lys laat 'n mens se oë rek. Dit is 'n konferensie van Hoër Onderwysinrigtings - en tog is "Loft" plotseling met verteenwoordigers Buthi en Tema uit die CI-stal daar! "Loft", prof. H. Hart van Toronto en die "Koinonia"-mense se name word dikwels saamgenoem - en die hele wêreld, veral die VSA, was met al wat voelhoring was, op die "koinonia"-verklaring ingeskakel. My indruk is dat die verklaring van buite geplant of geborg was. Dit het veral die VSA polities betrek - soos Nederland reeds gekondisioneer was rondom die ANC, CI, SARK en WRK-program.

Die tema van die konferensie was "The responsibility of Christian Institutions of Higher Education to Justice in the International Economic Order". Die formulering leen hom natuurlik pragtig om enige ekonomiese vraagstuk eensydig te verpolitiseer soos die neomarxisme en marxisme doen. Ek maak die afleiding dat die konferensie toe ook uit sy pad gegaan het om die hele wêreld te systap en by Suid-Afrika uit te kom. Die begrip "geregtigheid" (behalwe die voordragte van prof. T. v. d. W. en Lidney Rooy) sou daarom ook horisontaal aangepak gewees het.

Die taak van die Universiteit sou wees om 'n "protes" teen die bestaande politieke en ekonomiese sisteem te laat hoor. Die taak om gelowiges toe te rus vir hulle dienswerk in die heerskappy van Christus het geen nadruk ontvang nie.

Die agenda het op ' $n$ bepaalde aand voorsiening gemaak vir „discussions on Issues and Tensions among us". Dit het waarskynlik bedoel om die spanning VU en PU vir CHO op te klaar. Die agenda is egter gemanipuleer en het 'n vergadering onder leiding van die Calvin College geword waarin die $\mathrm{PU}$ vir $\mathrm{CHO}$ na aanleiding van die Koinonia-verklaring, in die beskuldigde bank geplaas is. Hoewel die VU offisieel afwesig was, was hulle tog al die tyd ook daar teenwoordig en aandadig. Die indruk van prof. B. was dat die verloop van die aand 'n daad van ,injustice" en onreg teenoor die PU vir CHO was. Die mense van die "Loft" was skynbaar die uitverkore geselskap.

'n Mens wonder hoe die „ere-doktor" Beyers Naudé op so 'n konferensie plotseling aktueel kan word! Ons het hier in die pers verneem van 'n poging om die motor en/of huise van Naudé en mev. Joseph met brandbomme te tref. Die skade was so gering dat ek selfs 
geen foto's in die pers gesien het nie. Nogtans het die voorsitter (prof. $\mathrm{K}$. Runia) heel spoedig die nuus daar ontvang en plegtig met deelneming 'n bomaanval op die huis van Naudé vermeld wat groot skade aangerig en mense beseer het. Gedagtig aan die (toevallige?) saamval van die opening van die vorige GES en die onluste in die Kaapstadse omgewing, wonder 'n mens of die ,bomaanval" nie ook geplant was met die oog op buitelandse gebruik in juis die kringe waarin Beyers Naudé tot heilige en enigste blanke Christen in SA verklaar is nie.

Die totaliteitsaanslag op SA kan so juis die „Calviniste” ook betrek en die PU vir CHO isoleer. So word die konferensie juis 'n geleentheid teen SA.

Die geniale beplanning en gerigte strategie van die aanval op SA en die rol wat "geestelike" vriende in die buiteland daarin bewustelik of onbewustelik moet speel, moet deur ons onder oë gesien word. Die tyd is verby dat ons met tipiese Afrikaanse beleefdheid, welmenendheid en naiwiteit kan aanneem dat ander sonder meer broeders in Christus is en hulle sal hou aan die norme van etiese gedrag wat jy in 'n konferensie van "christene" en "gereformeerdes" verwag. My kollega was geskok, waar hy van jongs af gehoor het van die Rooihuide wat die VSA bewoon het, om van New York, oor Chicago na Grand Rapids te reis en nooit een van hulle te sien nie. Op 'n navraag waar hulle dan is, het die Amerikaner geantwoord: Hulle is vroeëre jare gedeeltelik uitgeroei en vandag in reservate. Sommige Amerikaanse broeders het hiermee geen etiese probleem wanneer hulle die Koininia-verklaring in lyn met Carter se mense-regte-program aan die orde stel nie!

Tog verbly dit dat prof. B op die Konferensie 'n "silent majority" gewaar het wat nie die eensydige verpolitiseerde greep op die Konferensie goedkeur nie. Moet die Christelike Inrigtings nie ook noukeurig identifiseer nie? Wanneer die VU en mense soos prof. Mulder hulle so duidelik anti-blank SA verklaar, maak die GES en konferensies met hulle enige sin? Ek kan baie moeilik die sin en waarde sien van "konferensies", "ekumensiese sinodes" en die sogenaamde mode "dialoog" met mense wat vooraf besluit het wat hulle vir jou wil sê en geensins belang stel om na iets te luister wat jy antwoord nie.

Dit mag kras klink: ons is werklik naief indien ons dink dat ons nog die oorlog van die "gentlemans" teen die opmars van die linkse rewolusie kan voer. Dit is eenvoudig 'n feit dat hierdie mense enige geleentheid wat hulle "vyande" organiseer en bekostig, kunstig infiltreer, die agenda onopsigtelik manipuleer en verpolitiseer. Hulle wil die sisteem vernietig deur kragte in homself daartoe aan te wend. Iemand het dit al vergelyk met die tegniek van judo - jy gooi jou vyand met sy eie gewig om. Dit is makliker as die weg wat ons tradisioneel beoefen het, om met die waarheid voor oë in moeisame dialoog van argument teen argument, 'n uitputtende woordgeveg vol te hou.

\section{Gelukwensings}

Die proefskrif van dr. J. M. Vorster van Gobabis in die Departement Kultuurkunde aan die PU vir CHO oor "Kerk en Kleurvraagstuk en 
standpunte van die WRK en die GKN" is uiteraard ook vir die teologie van belang. Hy word van harte geluk gewens met hierdie kroon op sy arbeid. Ds. P. J. de Bruyn van Pretoria-Sunnyside het die aktuele onderwerp "Die plek van die mens in die etiek van H. M. Kuitert" vir die Th.M.-graad behandel en daarmee sukses behaal. Van harte geluk.

In die Skriflig bid ook dr. V. E. d'Assonville die seën van die Here toe met sy beroep as professor in Kerkgeskiedenis, Dogmageskiedenis aan die Teologiese Skool te Potchefstroom.

B.S.

\section{GTV-jaarvergadering}

Op Dinsdag 13 Junie het die jaarvergadering van die GTV in die Araratsaal by Pretoria-Oos plaasgevind. 'n Woord van hartlike dank aan die Gereformeerde Stigting, kerkraad en susters van PretoriaOos wat ons so gasvry ontvang en onthaal het.

Die tema van die jaarvergadering was: Die Christen in die wêreld van sosiaal-politiese strukture. Prof. L. F. Schulze het gepraat oor die kragte wat werksaam is in die sosiaal-politiese strukture en die spanninge wat daarin voorkom in hierdie wêreld, terwyl dr. K. S. van Wyk de Vries die lewe van die Christen in hierdie wêreld van sosiaal-politiese spanninge toegelig het. Die sprekers het op meesterlike wyse die aktualiteit van die tema by ons tuisgebring wat dan ook 'n lewendige en hoogstaande bespreking uitgelok het. Die voordragte is in hierdie uitgawe opgeneem.

Die vergadering is bygewoon deur predikante vanoor die land, professore en studente van albei teologiese skole.

Die volgende finansiële verslae is met hartlike dank aan ds. J. J. de Jager, sekretaris-penningmeester; mev. S. A. Louw, wat die administrasie van In die Skriflig behartig; en die ouditeur, mnr. J. R. Boot, ontvang en aanvaar:

\section{G.T.V. Hoofbestuur}

Finansiële verslag Junie 1977-Junie 1978

1. LOPENDE REKENING

\section{Inkomste}

Saldo op 7-6-77

8-6-77 Aan donasies (lede)

8-6-77 Vanaf Spaarrekening

8-2-78 Vanaf Spaarrekening

89,87
236,10
30,00
30,00

Uitgawes

7-6-77 Tjek 4 - Prof.

W. D. Jonker

7-6-77 Tjek 5 - Prof.

B. Spoelstra

7.6-77 Tjek $6-$ Mej.

J. M. Viljoen (tikster)

7-6-77 Tjek 7 - Susters

Linden (etes)

8-6-77 Kommissie Bank

6-2-78 Tjek 8 - Ds. A. J.

du Plessis (reisk.)

Saldo 13-6-78
30,00

30,00

20,00

272,00

50

24,00

9,47 
2. SPAARIEKENING

Inkomste

Saldo op 7-6-77

29-1-77 Rente

29-7-77 Rente

30-1-78 Rente
Uitgawes

$70,49 \quad 8-6-77$ Oorplasing L/rek. $\quad 30,00$

4,90 8-2-78 Oorplasing $\mathrm{L} /$ rek. $\quad 30,00$

$\begin{array}{ll}3,64 & \text { Saldo } 13-6-78 \\ 89,89\end{array}$

86

$\mathrm{R} 79,89$

R79,89

\section{IN DIE SKRIFLIG}

INKOMSTESTAAT VIR DIE PERIODE 1 MAART 1977 TOT 31 MEI 1978 (15 MAANDE)

Inkomste

Intekengeld

Donasies
3498,69

1061,48

Uitgawes

Drukkoste (5 uitgawes)

Administrasiekoste

2974,29

129,61

3103,90

Surplus vir die tydperk na opgeloopte fondse

1456,27

$\mathrm{R} 4560,17$

R4 560,17

BALANSSTAAT SOOS OP 31 MEI 1978

Opgeloopte fondse

Saldo op 1 Maart 1977

Plus rente op spaarrek.

Surplus inkomste vir die tydperk van 15 maande tot 31 Mei 1978
Verteenwoordig deur

$\begin{array}{rc}3890,30 & \text { Kontant in } \\ 362,60 & \text { spaarrekening } \\ & \text { Kontant in } \\ & \text { bankrekening }\end{array}$

1456,27
5113,44

595,73

R5 709,17

Mag die Here onse God die werksaamhede van die GTV in hierdie komende jaar ryklik seën en mag die Heilige Gees ons steeds die wysheid en die insig gee om die Woord van God onvervals in ons verenigings te laat spreek.

C. J. Malan (voors.). 